\title{
Vertebra Lomber Disklerde Meydana Gelen Bozulmaların Manyetik Rezonans Görüntüleme (MRG) ile Analizi
}

\author{
The Magnetic Resonance Imaging (MRI) Analysis of Deteriorations in the \\ Lumbar Spine Disks
}

Esra ÇOBAN BUDAK, Öğr. Gör., Kocaeli Üniversitesi Enformatik Bölümü, dideban_coban@yahoo.com

Mehmet Recep BOZKURT, Yrd.Doç.Dr., Sakarya Üniversitesi Mühendislik Fakültesi, mbozkurt@sakarya.edu.tr

ÖZET Günümüzde bel rahatsızlıkları kalp rahatsızlı̆̆ı şikayetlerinden sonra, ikinci sırada yer alan bir să̆lık sorunudur. Bel rahatsıliklarının tedavisinde dinlenmeden, cerrahi operasyona kadar geniş yelpazeli bir tedavi süreci uygulanmakta olup, bu tedavi süreçlerinin neden olduğu iş gücü kaybı oldukça yüksektir. Bel rahatsızlı̆̆ının seviyesine ilişkin tespit, uzman doktor tarafindan yapılan fizik muayene ve tıbbi görüntüleme tekniklerinden elde edilen veriler doğrultusunda elde edilmektedir. Bel rahatsızliklarının tespitinde kullanılan en yaygın tıbbi görüntüleme tekniği olan Manyetik Rezonans Görüntüleme (MRG) tekniği, özellikle yumuşak doku incelemelerinde yüksek güvenilirlikte sonuçlar vermektedir.

Çalışmada hastanın durumu hakkında karar verme aşamasında uzman doktora yardımcı olabilecek bir karar ă̆acı yapısının oluşturulması hedeflenmiş ve hastaların risk durumlarına göre tedavi yöntemlerinin belirlenebileceği ön görülmüştür. Bu amaçla, tam teşekküllü bir kamu să̆lık kuruluşundan elde edilen veriler çerçevesinde bir karar modeli oluşturulmuş ve her bir bel omuru için bu model ID3 karar ăgacı algoritması ile uygulanarak, karar ă̆acı yapıları çıkarılmıştır.

Anahtar Kelimeler: Bel rahatsızlıkları, Vertebra Lomber, MRG, karar ă̆acı, ID3 algoritması

ABSTRACT Today, low back disorders are health problem in the second place after complaints of heart disease. The treatment of low back disorders is a wide range from resting to surgical treatment process. These operation and treatment processes cause highly loss of manpower. Low back disorders' level diagnosis can be made by specialist doctors in accordance with the data obtained from physical examination and medical imaging. Magnetic Resonance Imaging (MRI) technique is the most common medical imaging technique used to determine low back disorders, gives results with high reliability especially on the soft tissue examinations.

In this study, it's aimed to develop a decision-making structure helpful to the specialist doctors to deciding patients' status, and is contemplated that treatment method can be selected due to patient's risk group. For this purpose, a decision modal was created from data set derived from a full-fledged public health organization, and, this decision modal was applied with ID3 decision algorithm for every lumbar disks and decision tree structures were determined.

Key Words: $\quad$ Low back disorders, lumbar spine, MRI, decision tree, ID3 algorithm 


\section{Giriş}

İnsan iskeletinin en temel ve bütünleştirici parçalarından olan omurga, aynı zamanda insan vücudunun organlar arası iletişimini ve yönetimini sağlayan sinirlerin toplanarak beyne ulaştığı omuriliğin koruyuculuğu görevini de üstlenir. Tıbbi terminolojide adı Lomber olan omurga, yukarıdan aşağıya baş (Cervical), sırt (Torakal), bel (Vertebral) ve kuyruk sokumu (Sakral) olarak dört ana bölüm ve 24 omurdan oluşur. Bu bölümlerden ilk üçü, omurganın kavisli alanlarını da ifade eder.

Çalışmaya konu olan Vertebral bölge rahatsızlıkları (bel ağnısı), tüm rahatsızlıklar içinde yaygınlık ve tıbbi yardım aramak bakımından ikinci en sık nedendir. Bel ağrısı şikayetleri sonucu hastalık izni nedeniyle iş gücü kayıplarının da \% 15'ini oluşturur (Koç, 2003). Bu tip hastalıkların teşhisinde, tıbbi görüntüleme cihaz ve yöntemleri gün geçtikçe artan önem kazanmıştır. Bilgisayarlı teknolojik sistemlerin gelişmesiyle birlikte karşımıza tıp elektroniği kavramı çıkmaktadır. Tıp elektroniği aynı zamanda biyomedikal olarak da söylenmektedir. Bu kavram, günümüzde sağlık alanında teşhis ve tedavi amacıyla kullanılan mekanik, elektronik cihaz ve sistemlerden oluşmaktadır. Günümüz modern tıbbının hastalıkların tanı ve teşhisinde; hekimlere kılavuzluk etmek amacıyla mühendislerce geliştirilen cihazlar, kısaca biyomedikal cihaz olarak anılır ve tamamıla yüksek özen ve dikkat isteyen süreçler sonucu üretilmiş cihazlardır. Bu cihazlar hekimlere, tıbbi uygulamalarda yüksek rahatlık ve konforu sunarken; hastaların bu müdahalelerden en az şekilde etkilenmelerini sağlamak için üretilirler. (Ünal,2008)

İnsan vücudunun belirli bir kesiminin ya da tümünün tıbbi amaçlı görüntülerinin çıkarılmasıyla mevcut hastalıkların bilgisi elde edilmiş olur. Tıbbi amaçlı görüntüler elektriksel, sonik veya radyolojik gibi birbirinden farklı yöntemlerle üretilir. Ancak radyolojik görüntülemede vücudun kesitsel görüntüsünün çıkarılması için X-1şınları veya Elektromanyetik alanlar kullanılır. (Ünal,2008) Tıpta kullanılan görüntüleme tekniklerine Bilgisayarlı Tomografi Cihazları (BT), Manyetik Rezonans Görüntüleme(MRG), Ultrasonografi (US), X-Ray (Röntgen) örnek verilebilir.

Oyar'a göre MRG, görüntülemenin bel ağrısı şikayetlerinde en güvenilir sonuç veren görüntüleme yöntemidir ve bu görüntüleme tekniği yumuşak doku kontrast çözümleme gücü en yüksek görüntüleme yöntemi olması nedeniyle tercih edilmektedir. Böylece yumuşak dokuların yüksek kontrast çözünürlüğü altında birbirinden ayrıştırılması, iç yapılarının daha iyi bir şekilde ortaya konmasını kolaylaşmaktadır. MRG ile hastanın pozisyonunu değiştirmeden çok düzlemden görüntüler elde edilebilir. (Oyar,2008) 


\section{Menyetik Rezonans Görüntüleme (MRG)}

Manyetik Rezonans Görüntüleme (MRG) cihazı, manyetik titreşim anlamına gelen bir kesit görüntüleme yöntemidir. MRG cihazı protonların manyetik alan altındaki titreşimlerinden yola çıkarak oluşturulmuş ve tanı amaçlı kullanılmaktadır (Ünal,2008) Radyolojik görüntüleme yöntemleri arasında en çok ilgi çeken yöntem MRG'dir. Manyetik rezonans görüntülemede dijital(sayısal) olan görüntüler, bilgisayar teknolojisinden yararlanılarak kesit görüntüler elde edilir.

MRG yönteminin önemli bir avantajı hastanın pozisyonunu değiştirmeden her düzlemde görüntü alabilmesidir. MRG'nin kullandığı enerji radyo dalgalarıdır.

Radyofrekans (RF) olarak isimlendirilen bu enerji, elektromanyetik radyasyon içerisinde yer alır. Veri kaynağı hücre sıvısı ve lipidler içerisindeki hidrojen çekirdeğidir yani protonlardır. (www.tumradder.com)

\subsection{MRG'nin Tarih Kronolojisi}

Elektrik ve manyetizma konusunda bilimsel çalışmalar 18. yüzyılın sonlarına doğru başlamıştır. Bu alanda çalışma yapan önemli ilk isimler: Ampere, Bohr, Coulomb, Curie, Faraday, Gauss, Hertz, Oersted, Tesla ve Weber`dir.

- 1939 yılında Dr.Isador Rabi ve arkadaşları NMR(Nükleer Manyetik Rezonans) prosesini gözlemişlerdir.

- 1973 yılında Paul Lauterbur NMR ile insan vücudunun görüntülenebileceğini göstermiştir.

- 1980 yılında Aberdeen grubu tarafından görüntü elde edilmesinde iki boyutlu Fourier Dönüşümü tekniğinin kullanılabileceği ortaya konmuştur.

- 1984 yılında ilk defa kontrast madde kullanılmaya başlanmıştır.

- 1986 yılında ise hızlı görüntüleme yöntemleri kullanılmaya başlanmıştır. (Karahasanoğlu, 2007)

Tıbbi görüntüleme tekniklerinden olan MRG, başta beyin, omurilik, bel, kas-iskelet sistemi, tümörler ve bazı kalp hastalıkları olmak üzere çeşitli klinik değerlendirmeler için sık kullanılmaktadır. (Karaoğuz,2012) 


\subsection{MRG Aygitı Bileşenleri}

MR aygıtı üç ana parçadan oluşmaktadır;

- Veri toplama bölümü: Bu bölümün ana parçası çok güçlü manyetik alan üreten miknatıslardır. Genel amaçlı MR'lerin manyetik alan gücü genellikle 1.0-1.5 Tesla civarındadır. Ortasında hastanın içine sokulduğu bir tüneli vardır. İçlerinde, kesit alabilmek için ana manyetik alanı kontrollü olarak hafifçe değiştiren ek sargılar bulunur. Bunlara gradiyent sargılar adı verilir.

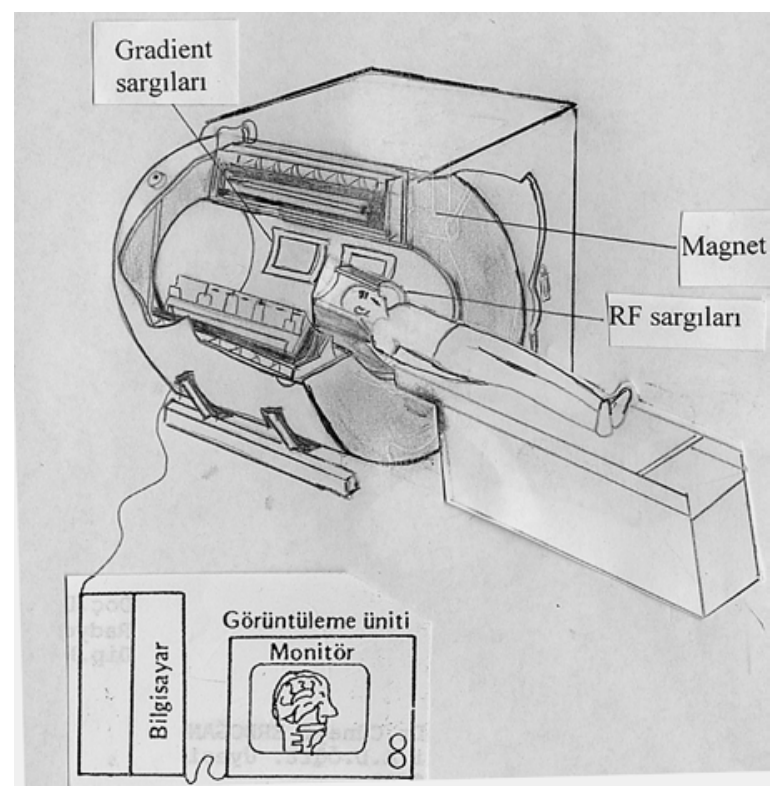

Şekil 1: MRG Aygıtı ve Bileşenleri

Kaynak: ttp://www.baskent.edu.tr/ aerdamar/Bolum2.pdf

Üç düzlemde yerleştirilmiş bu sargılar sayesinde hastanın pozisyonu değiştirilmeden her üç düzlemde de kesit alınabilir. Veri toplama bölümünün diğer önemli parçası RF sargılarıdır. RF sargıları RF pulsunu gönderen ve sinyalleri toplayan aygitlardır. İncelenecek bölgeye ne kadar yakınsa veriler o kadar hassasiyetle elde edilir. Her vücut bölgesine göre üretilmiş RF sargıları vardır. İncelenecek bölgeye RF sargısı yerleştirildikten sonra hasta mıknatısın tüneli içerisine sokulur.

- Bilgisayar sistemi: Veriler bilgisayarlarda işlenerek görüntüler oluşturulur.

- Görüntüleme birimi: Yüksek çözünürlüğe sahip bir monitörde görüntüler seçilir, işlenir ve filmler üzerine kaydedilir. Bu birim aynı zamanda sistemin kontrol ünitesidir. (www.tumradder.com) 


\subsection{MRG'de Görüntü Oluşumu}

Bir MR görüntüsünün elde edilişi şu şekilde özetlenebilir;

- İlk olarak hasta güçlü bir manyetik alan içerisine yerleştirilir. Daha sonra radyofrekans enerjisi ile vücuttaki protonlar uyarılır. Protonlar bu enerjiyi alırlar ve aldıkları enerji miktarlarına göre saparlar.

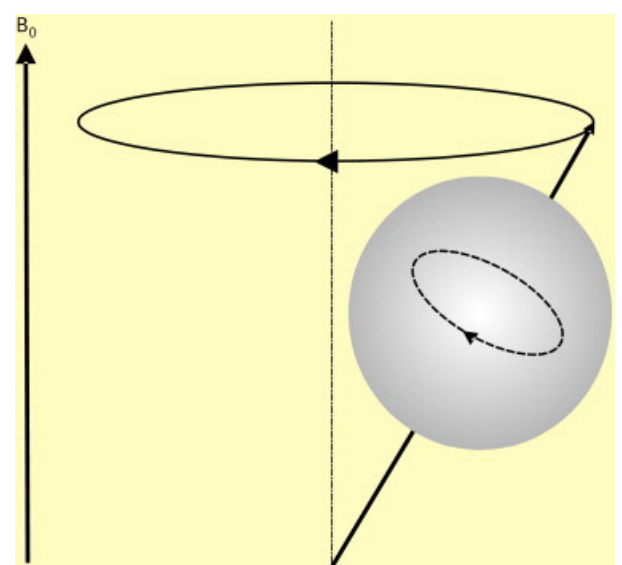

Harici manyetik alan etkisine maruz kalan hidrojen atomları, manyetik alan yönünde Larmor frekansıyla $\left(B_{0},\right)$ döner.

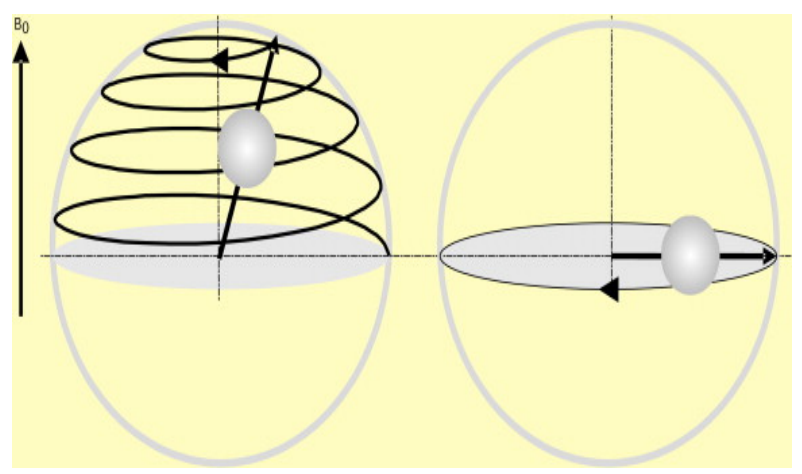

$90^{\circ}$ uyarma etkisi ile belli bir süre için statik dış manyetik alan uygulandığında, Larmor (rezonans) frekansta salınan BO, (sol) dik olan bir düzlem içine döner. Salınan alan kaldırılığında, mıknatıslanma rezonans frekansı (sağ) bir düzlemde döner.

Şekil 2: MRG'de Görüntü Oluşumu Kaynak: http://www.sciencedirect.com/science/article/pii/S1877132710001776

- Sonra radyofrekans enerjisi kesilir ve protonlar ekski konumlarına dönerler. Protonlar eski durumlarına dönüş süresinde bir sinyal yayınlarlar. MR görüntüleri bu sinyallerden yararlanılarak oluşur.

- $M R$ ‘da gri tonlarda görüntü oluşur fakat $M R$ 'da inceleme protokolüne göre tonlar değişebilmektedir.

- Beyaz ve açik tonlar artmış sinyal bölgelerini, siyah ve koyu tonlar ise sinyalin az ya da olmadığı bölgeleri gösterir. 


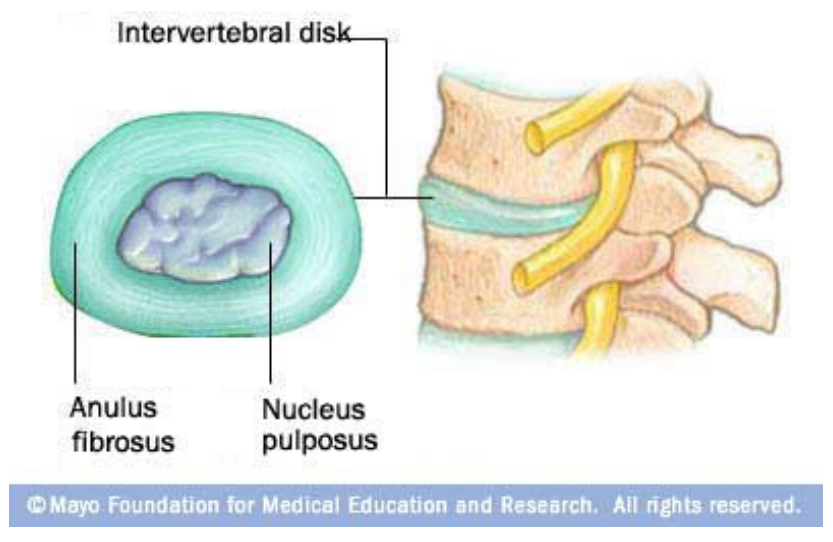

Şekil 3: Lomber Vertebra

Yumuşak doku tetkiklerinde en iyi yöntem MR 'dır. MR 'da akım doğrudan görüntülenebildiği için kontrast madde kullanmadan anjio görüntüleri elde edilebilir. (www.baskent.edu.tr)

\section{Bel Bölgesi Omurları (Lomber Vertebra )}

Omurga, insan vücudunun dik durmasını, diğer taraftan da içindeki kanaldan geçen omuriliğin korunmasını sağlayan kemik zincirine verilen addır. Omurilik ise beyin kökünden başlayarak, kuyruk sokumuna kadar uzanan ve beyin ile organlar arasındaki irtibatı sağlayan merkezi sinir sistemine verilen addır. Omurilik bunun yanında tek başına refleksleri de kontrol etmektedir. (www.tofd.org.tr) Lomber Vertebra, vücuda sağlam ve esnek bir yapı kazandıran beş omurun birleşmesiyle oluşan bir yapıdır. Lomber vertebra, tüm omurga uzunluğunun \%25'ini oluşturur. Yandan bakıldığında konkavitesi arkaya bakan ve lomber lordoz adı verilen bir eğrilik yapar (Murat, 2007).

Omurganın üç biyomekanik fonksiyonu vardır. Bunlar; gövdeyi desteklemek, spinal kordu ve sinir köklerini korumak ve gövde ile başın hareketini sağlamaktır. Omurgada fonksiyonların yerine getirilmesi İki kısımdan oluşur; ön kısmı iki vertebra cismi ve bunların arasında yer alan intervertebral diskten meydana gelir ve görevi ağırlık taşıma ile vertebral kolona destek sağlamaktır. Arka kısmı ise nöral yapıları korur ve lomber bölgenin hareketini organize eder. Omurganın hareketi, kasların ve sinirlerin koordine çalışması ile gerçekleşmektedir. Tüm omurganın hareketi farklı farklı hareket segmentlerin birlikte çalışması ile oluşmaktadır. (Yazıcı Demir, 2011) 


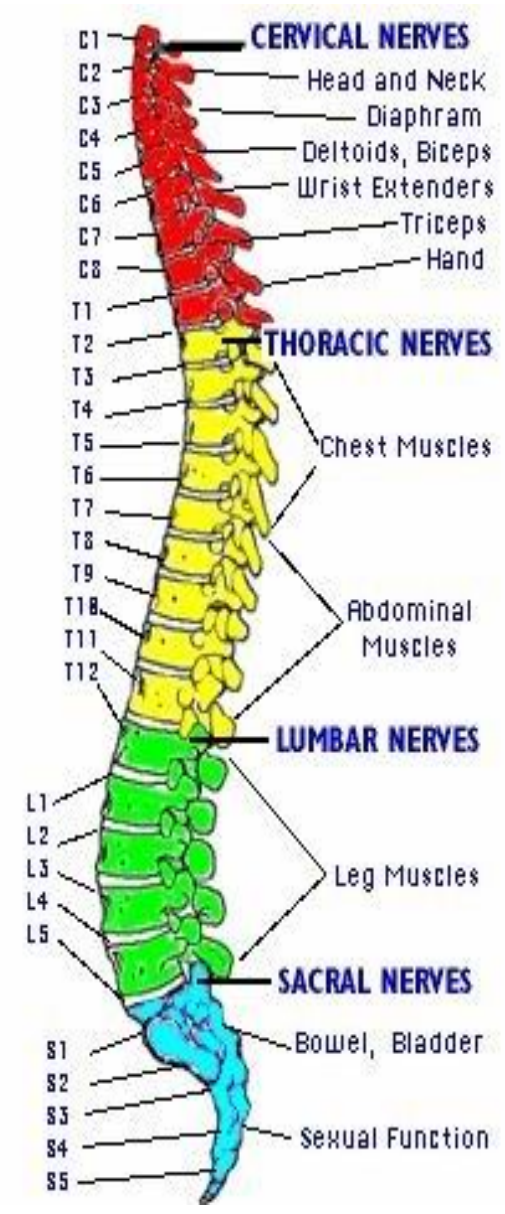

Şekil 4: Omurga şekli

Kaynak: http://lokman-hekim.net/hastaliklar/belfitigi.asp

Lomber Vertebral kolonun fonksiyonel birimini, nukleus pulpozus, anulus fibrosus ve kıkırdak son plaklardan oluşan intervertebral disk, komşu vertebra cisimlerinin yarısı, faset eklemler ile omurga kanalı ve intervertebral foramenler ile aynı seviyede bulunan yumuşak dokular oluşturmaktadır.

Omurgayla ilgili rahatsızlıklar genel olarak, üç sınıfa ayrılabilir. Bunlar; kemik yapıyı oluşturan bileşenlerdeki (omur) deformasyon ve bozuklukların neden olduğu rahatsızlıklar, omur kemikleri arasında yer alan ve intervertebral disklerdeki rahatsızlıklar ve omurgayı çevreleyen kas dokusundaki rahatsızlıklardır. Genellikle ilk iki rahatsızlık türü birlikte görülmektedir. Birinci tip rahatsızlıklar (kemik yapılarda dejenerasyon) yaşa bağlı olarak gelişen bir nitelik gösterir, daha az oranda da travmalara (kırıklar, faset sendromları, kazalar gibi) bağlı gelişir. 50 yaş kadınların yaklaşık \% 60 inda, erkeklerin ise \% 80 inde lomber vertebralarda dejeneratif değişikliklere rastlanır. 70 yaşın üzerindeki her insanda ise mutlaka dejeneratif değişiklikler mevcuttur (Sesli, 2011). 
Yaslanma ve dejenerasyon ile birlikte disklerde su ve proteoglikan kaybının yanında kollojen miktarında artıs görülür. Nukleus içinde küçük ayrılmalar ortaya çıkar. Nükleus içerisindeki artan kollajen içerigine baglı olarak diskte sinyal kaybı olusur. Dejenerasyonla birlikte disk yüksekliginde azalma baslar (Çelikyay, 2008).

Omurgaya bağlı bel rahatsızlıkları ve en yaygını olan durum ise; omur kemikleri arasında amortisör görevi gören ve insan vücudunun gövde kısmının esnekliğini sağlayan intervertebral disklerde meydana gelen bozulma ve deformasyonlardır. Bu deformasyonlar, diskin iç kısmını oluşturan nucleus pulposusdaki sıvı kaybı, diski çevreleyen anulus fibrosusun zayıflaması ve yırtılması, intervertebral foramenler arasındaki bağlantılarda zayıflama ve işlev kaybıdır. Bu bozulmalar sırasıyla disk yüksekliğinde azalma, diskin omurga mesafesinden dışarıya doğru taşması (Bulging), disk çeperinin yırtılarak nucleus pulposusun dışarıya taşması (Hernie), nöral foremenlerde daralma etkilerine tek başına veya birlikte neden olmaktadir.

Omurilik, L1 disk seviyesine kadar tek parça olarak gelir ve bu seviyeden sonra aşağıya doğru dallanarak bir kese içinde devam eder. Bu keseye "Tekal Sak" adı verilmektedir. Her disk seviyesinde, o bölgeye ait sinirler omurganın sağ ve sol yanlarından alt ve üst omurların faset eklemleri ile omur gövdesi arasında kalan kanallardan dışarıya çıkar. Bu çıkan sinir ucuna "Sinir Kökü (Nöral root)" adı verilir.

Tablo 1: Lomber Disk Seviyelerinde Azalma ve Etkilediği Bölgeler*

\begin{tabular}{|l|l|l|l|}
\hline \multicolumn{5}{|c|}{ Lomber Disk Seviyesi } \\
\hline & L3-4 & L4-5 & L5-S1 \\
\hline Lomber disklerin yüzde & $\% 3-4$ & \%40-45 & \%45-50 \\
\hline Genellikle basıya uğr kö & L4 & L5 & S1 \\
\hline Motor kuvvetsizlik & diz ekstansiyonu & $\begin{array}{l}\text { ayak ve ayak parmak- } \\
\text { larının dorsal fleks }\end{array}$ & $\begin{array}{l}\text { ayak ve ayak parmak- } \\
\text { larının plantar fleks }\end{array}$ \\
\hline Parestezi ve hipoestezile & $\begin{array}{l}\text { anterior uyluk, } \\
\text { medial bacak, medial } \\
\text { malleol }\end{array}$ & $\begin{array}{l}\text { Bacağın ön dış kısmı, } \\
\text { baş parmak }\end{array}$ & $\begin{array}{l}\text { Bacağın arka kısmı, } \\
\text { ayak tabanı }\end{array}$ \\
\hline Refleks azalması & Patella & - & Aşhil \\
\hline
\end{tabular}

(* Kaynak: Koç, 2003ww.belgeler.com/blg/1ksq/disk-hern-2003)

Yukarıda bahsi geçen omurga rahatsızlıkları gerçekleşme seviyelerine göre sinir uçlarına ve Tekal Sak'a baskı uygulamaları durumunda hastanın yaşam kalitesini etkileyen ve son noktada "ayak düşmesi" olarak da bilinen organların kontrolünde zorluklara ve hatta bölgesel yetenek kayıplarına neden olabilmektedir. 


\section{Gereç ve Yöntem}

Kamu hizmeti veren tam teşekküllü bir sağlık kuruluşunda 1 Mart - 5 Nisan 2013 tarihleri arasında Beyin Cerrahi, Nöroloji, Ortopedi ve Radyoloji (Acil) servislerinden Manyetik Rezonans Görüntüleme talebiyle Radyoloji servislerine gelen ve görüntüleme işleminin ardından bir uzman Radyolog hekim tarafından Görüntüleme Raporu hazırlanan 65 hastanın MRG raporları veri setinin temelini oluşturmaktadır. MRG rapor verileri 37'si bayan, 28'i erkek hastadan oluşmaktadır. Tüm raporlarda Lomber Vertebral bölgesine ait bulgu ve değerlendirmeler ele alınmış olup, kullanılan kavramların nominal ifadelere dönüştürülerek değerlendirmesi yapılmıştır. Nominal değerlere dönüştürme işlemi sırasında veri madenciliği ön işlem aşamaları takip edilmiştir. Bu işlemler sırasıyla;

- Genel data setinde bulunan 397 MRG raporu arasından ilgili olabileceği düşünülen servislere göre veri temizlemesi yapılarak, Beyin Cerrahi, Nöroloji, Ortopedi ve Radyoloji (Acil) servislerinden sevk edilen hastalara ait raporlar değerlendirilmiştir.

- Rapor verilerinde bulunan uzun açıklama ve ifadeler incelenerek, anormal durumları tanımlayan belirgin kavram ve kısa tanımlara dönüştürülmesi yapılmıştır. Bu dönüştürme sonucu veri setinin sütun başlıkları elde edilmiştir.

- Verilerin data setine işlenmesi sonrasında bazı sütunlardaki veriler, yeni bir sütunda birleştirilmiştir. [Örneğin Lomber Vertebra'nın her bir omurundan çıkan sinirlerin sağ ve sol çıkış noktalarına (sinir kökleri) baskı uygulayan herhangi bir taşma durumu (Bulging veya Hernie) önce ayrı ayrı değerlendirilmiş, daha sonra risk analizinde eşit değerde olmaları nedeniyle birleştirilmiştir.]

- Data setindeki veriler bi-nominal değerler olduğundan Min-Max veya Z-Score gibi normalleştirme işlemleri uygulanmamıştır.

Hastaların bel ağrısı şikayetine neden olan faktörlerin, Lomber Vertebradaki disklerden herhangi bir ya da birkaçında meydana gelen bozulmaya bağlı olup olmadığı ve bu bozulmanın yaşam kalitesini etkileme düzeyi risk durumu olarak değerlendirilmiş ve "Çok Yüksek, Yüksek, Orta ve Düşük" olarak dört kategoriye ayrılmıştır. Bu risk durumlarının hastanın tedavi süreci hakkında önbilgi vereceği kabül edilmiştir. Veri setinde bulunan verilerin kategorilere göre sinıflandırılması ve benzer durumdaki yeni bir verinin risk durumunu doğrudan belirleyebilmek amacıyla karar ağaçları ile sınıflandırma algoritmalarından ID3 algoritması kullanışmıştır. Bu algoritmanın kullanılma nedenlerinden en önemlisi verilerin nominal değerler olmasıdır.

ID3 karar ağacı sınıflandırma algoritması Quinlan tarafından geliştirilen algoritmalardan biridir. Quinlan'e göre veri, bir özelliğe göre bölündüğünde elde edilen her bir veri kümesinin belirsizliği minimum ve dolayısıyla bilgi kazancı maksimum ise en iyi seçim yapılmıs demektir. ID3 algoritmada tek tek özellik vektörleri incelenir ve en yüksek bilgi kazancına sahip özellik, ağaçta dallanma yapmak için tercih edilir. Algoritma sadece 
nominal veri ile çalısan bir yöntemdir. Her iterasyonun ilk adımında veri örneklerine ait sınıf bilgilerini tasıyan vektörün entropisi[1] belirlenir. Daha sonra özellik vektörlerinin sınıfa bağımlı entropileri hesaplanarak ilk adımda hesaplanan entropiden çıkartılır. Bu sekilde elde edilen değer ilgili özellik vektörüne ait kazanç değeridir. En büyük kazanca sahip özellik vektörü ağacın o iterasyonda belirlenen dallanmasını gerçeklestirir. (Orhan, 2012)ID3 algoritmasında verilerin sınıflandırılma işlemi iki adımda olmaktadır.

a) Birinci adım, veri setine göre rastgele seçilen eğitim verisine, niteliklere (attribute) uygun olarak sınıflayıcı model (Öğrenme model) oluşturulur. Böylece sinıf modelinde sınıflandrma kuralları kararlaştırılmış olur.

b) İkinci adım, belirlenmiş olan kurallar aynı şekilde tets verisine uygulama modeli (apply model) uygulanır. Model kurallarına göre yeni bir kaydında risk durumu belirlenmiş olur. (Özkan,2008)

Karar ağaçlandırmaları ile sınıflandrma algoritmasından olan ID3 algoritmasının tıbbi veri seti ile analizini yapabilmek için açık kaynak kodlu veri madenciliği programı olan RapidMiner 5.3 kullanılmıştır.

\section{Bulgular ve Değerlendirme}

Bel ağrısı rahatsızlıklarından dolayı çeşitli servislerde sevk edilen hastaların Lomber Vertebra MRG görüntülerinin uzmanlar tarafından yorumlanarak yazılan raporlarının risk analizi yapılmıştır. Çalışmada 379 MRG raporundan 65 rapor seçilen servislere göre değerlenmeye alınmıştır. Lomber Vertebra omurlarındaki rahasızlıklar; hastaların şikayetlerine, MRG rapor verilerini yorumlayan uzmanlarca ve doktorlar tarafindan yapılan fiziksel muayenelere göre netleşmektedir. Çalışmada omurlarda oluşan nedenlere göre (Tekal Keseye Bası, Sinir Köklerine Bası, Nöral Foramenlerde (NF) Daralma, Bulging, Hernie gibi) risk durum analizi yapılarak hastaların daha iyi bir yaşam sürebilmeleri için tahminler yapılmaktadır. Her bir hastanın MRG raporunda Lomber Vertebra bölgesinde bulunan omurlarda bir veya daha fazla bulgu ortaya çıkabilmektedir. Unutulmaması gereken nokta bu omurlardaki bulgulara göre öncelikle hastaya dinlenme, ağrı kesici desteği, kaş gevşetici desteği, sıcak - soğuk tedavisi, fizik tedavi, epidural steroid yüklemesi gibi konservatif tedaviler uygulanmaktadır. Rahatsızlığın müzmünleşmesi veya riskin yükselmesi durumlarında doktorlar tarafından cerrahi müdahele de seçenekler arasına girmektedir (nucleusanimation, 2011).

Lomber Vertebra disklerinin her biri ayrı ayrı değerlendirilmekte ve bulgulara göre değerlendirmeler yapılmaktadır. Eğer genel olarak omurlarda risk durumu çok yüksek olursa doktorlar tarafından ameliyat sadece bir omurda yapılmaktadır. Daha sonra risk durum analizine göre tedavi veya ilerleyen dönemlerde ameliyat kararı alnmaktadır. Bel ağrısına neden olan omur ve disk rahatsızlıkları daha çok L4-5 veya L5-S1 omurunda

\footnotetext{
${ }^{1}$ Entropi, bir sistemdeki belirsizliğin ölçüsüne denir. S veri kümesinin entropisi $\mathrm{H}(\mathrm{S})=--\sum_{i=1}^{n} p i \log 2(p i)$
} 
görülmektedir. Değerlendirme raporlarının nominalleştirilmesi sonucu elde edilen L5-S1 örnek veri seti aşağıdaki gibidir. Öncelikle bel ağrısının sonucunda ortaya çıkan bulgulara göre RapidMiner programında eğitim seti için bir sınıflayıcı modelin oluşturulması gerekmektedir. Rastgele alınan eğitim veri setimizge göre sınıflayıcı modelimiz aşağıdaki gibidir;

- Her bir hastaya ait verilerin "Tekal Sak'a" veya "Sinir Köklerine" bası bulgusunun olup olmadığına bakıldı. Eğer bası varsa, risk durumu "Yüksek", yoksa "Düşük" olarak belirlendi. (Şekil ? - O sütunu)

- Bası riski ile taşma durumu (Bulging yada Hernie) arasındaki ilişkiye bakılarak;

a) Eğer bası riski "Yüksek" ve taşma varsa risk durumu "Çok Yüksek",

b) Eğer bası riski "Yüksek" ve taşma yoksa risk durumu "Yüksek",

c) Eğer bası riski "Düşük" ve Bulging veya Hernie varsa risk durumu "Orta",

d) Eğer bası riski "Düşük" ve Bulging veya Hernie yoksa "Düşük" olarak risk durumu belirlenmiştir.

Eğitim veri setinde belirlenen karar ağacı kurallarına göre test veri seti üzerinde de sınıflandırma kuralları uygulama modeli (apply model) ile ID3 algoritmasını kullanarak ve doğruluk analizi yapılarak veriler sınanmıştır. Veri setindeki (örneğin L5-S1 ) sütun adlarına göre id (Kabül No) ve label (Genel Risk Durumu) tanımlanmıştır. Ayrıca veri setinde sınıflandırma ağaç algoritmasına girmeyecek olan sütun adlarında ise onay kutularındaki aktiflik kaldırılmıştır. Burada Sinir Köküne Bası L ve $R$ nitelikleri yerine veri birleştirme yapılarak Sinir Köküne Bası niteliği olarak alınmıştır. Yine nöral foramenlerde (NF Daralma L ve R) nitelikleri yerine aynı şekilde NF Daralma niteliği olarak birleştirilmiştir.

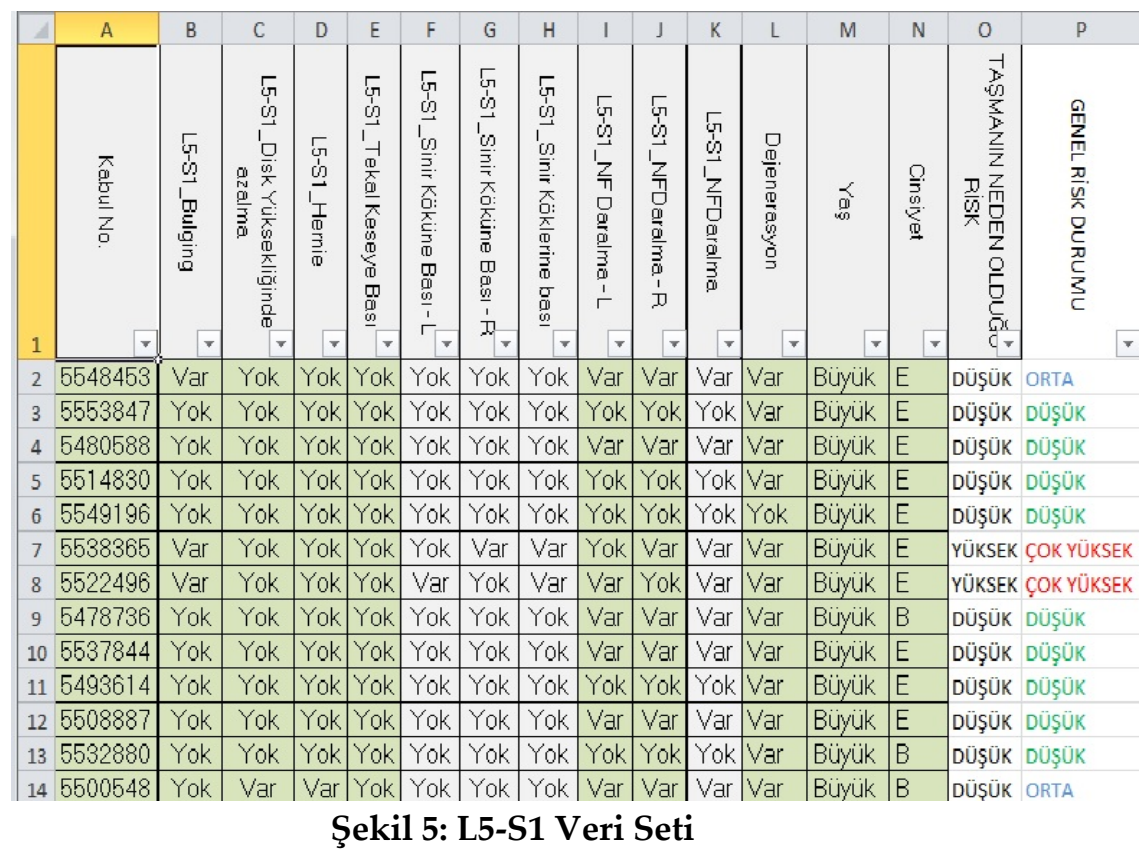


ID3 sınıflandırma algoritması akış şemalarına benzemektedir. Her bir nitelik (attribute) bir düğüm tarafından temsil edilmektedir. Dallar ve yapraklar ağaç yapısının elemanlarıdır. En son yapı "yaprak", en üst yapı "kök" ve aralarda kalan yapılarda "dal" olarak algoritmada isimlendirilmektedir (Özkan, 2008). Veri setinde seçilen label alanı ID3 ağacının yapraklarını oluşturmaktadır. Sınıflayıcı model kurallarına ve setteki nitelik (attribute) değerlerine göre en uygun ağaç şeması oluşturulmaktadır. (Şekil6)

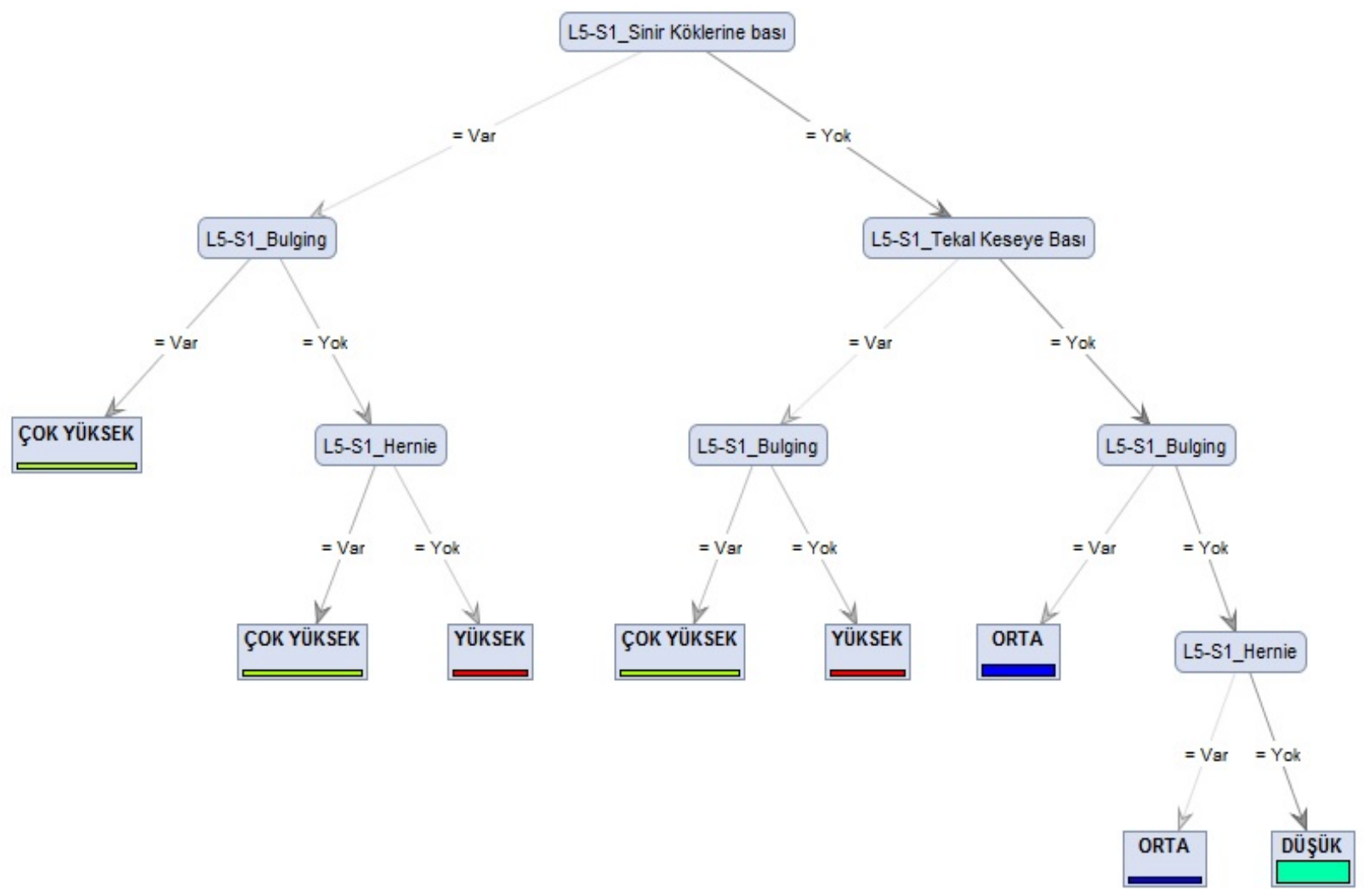

Şekil 6: L5-S1 veri setine göre ID3 Sınıflandırma Algoritmasının Ağaç Yapısı

Yukarıdaki ID3 sınıflandırma ağaç yapısının programdaki karar algoritması kodlaması aşağıdaki gibidir;

\section{Tree}

L5-S1_Sinir Köklerine bası = Var

| L5-S1_Bulging = Var: ÇOK YÜKSEK $\{$ ORTA=0, DÜŞÜK =0, ÇOK YÜKSEK =3, YÜKSEK=0 $\}$

| L5-S1_Bulging $=$ Yok

| | L5-S1_Hernie = Var: ÇOK YÜKSEK $\{O R T A=0$, DÜŞÜK =0, ÇOK YÜKSEK=2, YÜKSEK=0 $\}$

| | L5-S1_Hernie = YoK: YÜKSEK $\{$ ORTA=0, DÜŞÜK=0, ÇOK YÜKSEK=0, YÜKSEK=1 $\}$

L5-S1_Sinir Köklerine bası $=$ Yok

| L5-S1_Tekal Keseye Bası = Var 


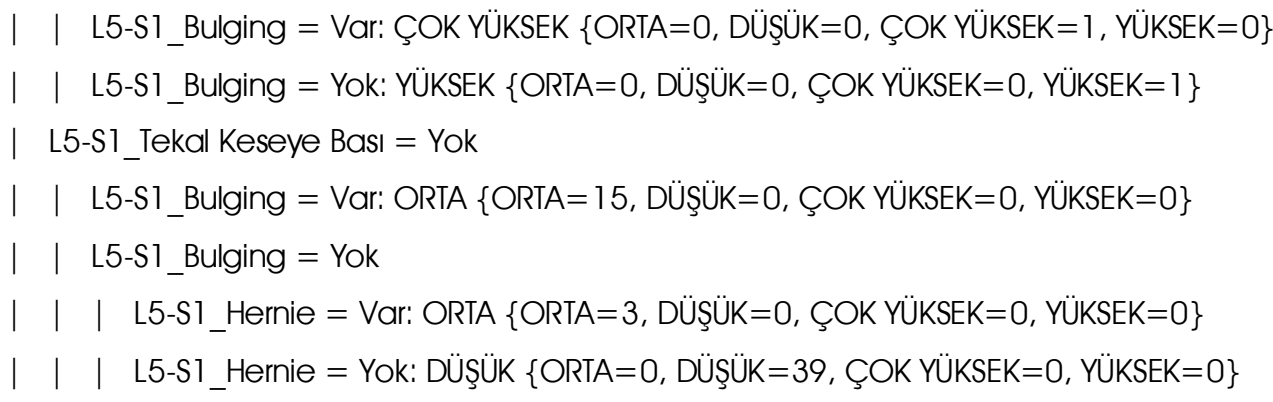

Tablo 2: L5-S1 Lomber Vertebra Omurundaki Veri Seti Doğruluk (Accuracy)

\begin{tabular}{|c|c|c|c|c|c|}
\hline \multicolumn{5}{|c|}{ (1) Multiclass Classification Performance $\bigcirc$ Annotations } & \multirow[t]{2}{*}{ 用 } \\
\hline \multicolumn{5}{|c|}{ ( Table View $\bigcirc$ Plot View } & \\
\hline \multicolumn{6}{|l|}{ accuracy: $89.47 \%$} \\
\hline & true ORTA & true DÜȘÜK & true ÇOK YÜKSEK & true YÜKSEK & class precision \\
\hline pred. ORTA & 4 & 0 & 0 & 0 & $100.00 \%$ \\
\hline pred. DÜȘÜK & 0 & 11 & 0 & 0 & $100.00 \%$ \\
\hline pred. ÇOK YÜKSEK & 0 & 0 & 2 & 2 & $50.00 \%$ \\
\hline pred. YÜKSEK & 0 & 0 & 0 & 0 & $0.00 \%$ \\
\hline class recall & $100.00 \%$ & $100.00 \%$ & $100.00 \%$ & $0.00 \%$ & \\
\hline
\end{tabular}

Bel rahatsızlıklarının en çok görüldüğü L5-S1 Lomber Vertebra omuruna göre yapılan ID3 karar ağacı sınıflandırma algoritmasındaki analiz değerlendirmeleri diğer omur bölgelerinde de yapılarak, sınıflandırma algoritmasındaki doğruluklar da sırasıyla aşağıda gösterilmiştir;

\section{- L1-2 Vertebra Lomber ID3 Algoritma Grafiği , Karar Ağac1 Algoritması ve}

\section{Doğruluk Tablosu:}

L1-2 Vertebra Lomber veri setinde "Sinir Köklerine Bası" niteliğinin bulunmaması ve "Yüksek Risk" sınıfa ait verilerin oldukça az olması, karar ağacının dallanma sayısını azaltmıştır. Bu durun, literatürde konu ile ilgili bilgileri de doğrulamakta olup, bel ağrılar ile ilgili omurga rahatsızlıklarında L1-2 diskinin en az etkiye sahip olduğunu göstermektedir. 


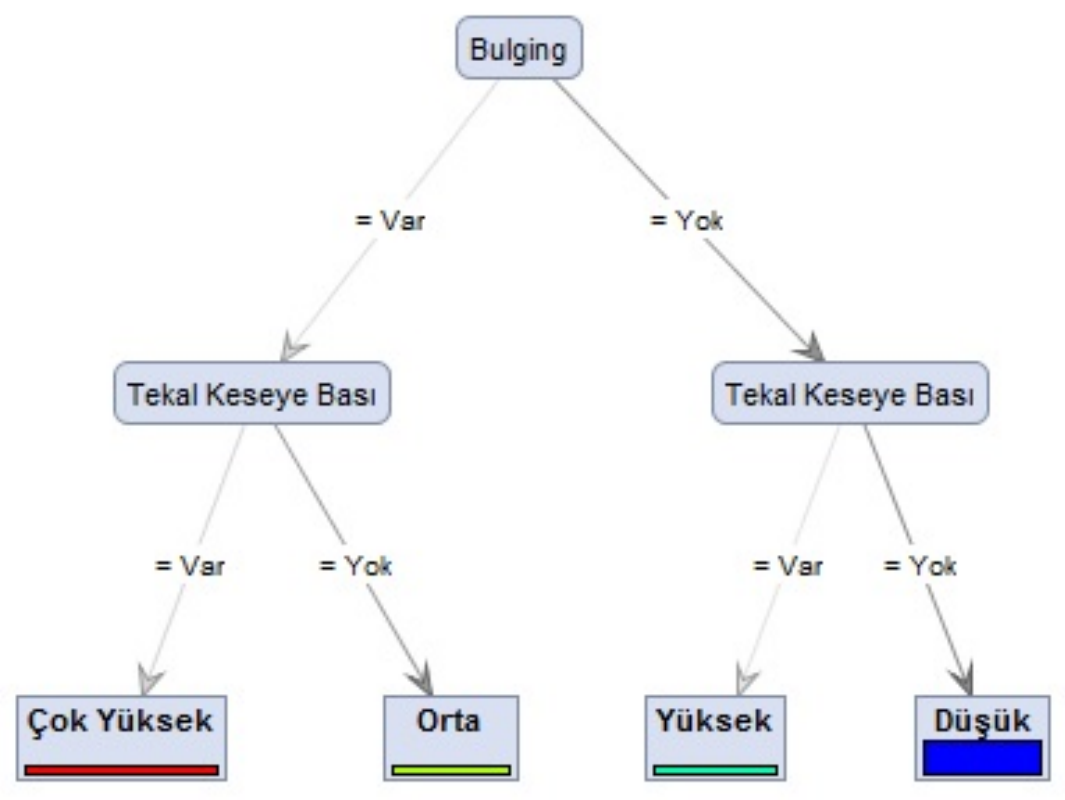

Şekil 7: L1-2 Veri Setine Göre ID3 Sınıflandırma Algoritmasının Ağaç Yapısı

Tree

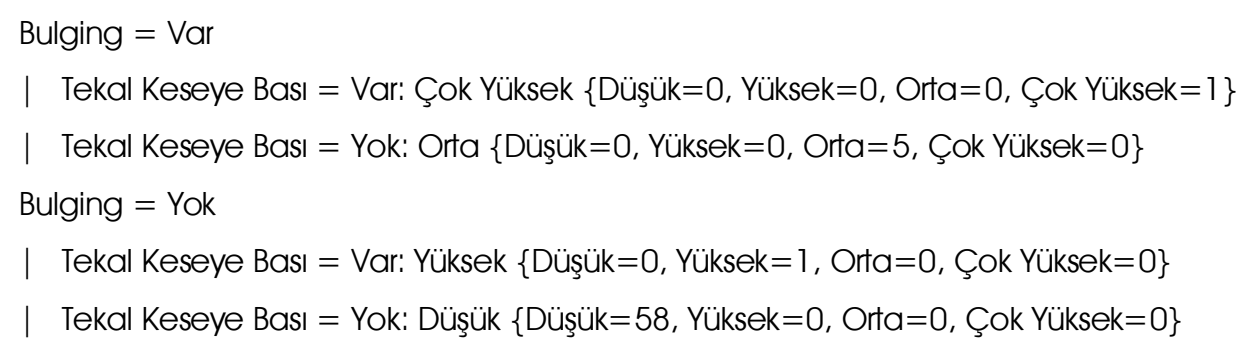

Tablo 3: L1-2 Lomber Vertebra Omurundaki Veri Seti Doğruluk (Accuracy)

\begin{tabular}{|c|c|c|c|c|c|}
\hline \multicolumn{5}{|c|}{ - Multiclass Classification Performance $\bigcirc$ Annotations } & \multirow[t]{2}{*}{ 圆 } \\
\hline (-) Table View & liew & & & & \\
\hline \multicolumn{6}{|c|}{ accuracy: $94.74 \%$} \\
\hline & true Düşük & true Yüksek & true Orta & true Çok Yüksek & class precision \\
\hline pred. Düşük & 15 & 0 & 0 & 0 & $100.00 \%$ \\
\hline pred. Yüksek & 0 & 0 & 0 & 1 & $0.00 \%$ \\
\hline pred. Orta & 0 & 0 & 3 & 0 & $100.00 \%$ \\
\hline pred. Çok Yüksek & 0 & 0 & 0 & 0 & $0.00 \%$ \\
\hline class recall & $100.00 \%$ & $0.00 \%$ & $100.00 \%$ & $0.00 \%$ & \\
\hline
\end{tabular}

- L2-3 Vertebra Lomber ID3 Algoritma Grafiği , Karar Ağacı Algoritması ve Doğruluk Tablosu: 


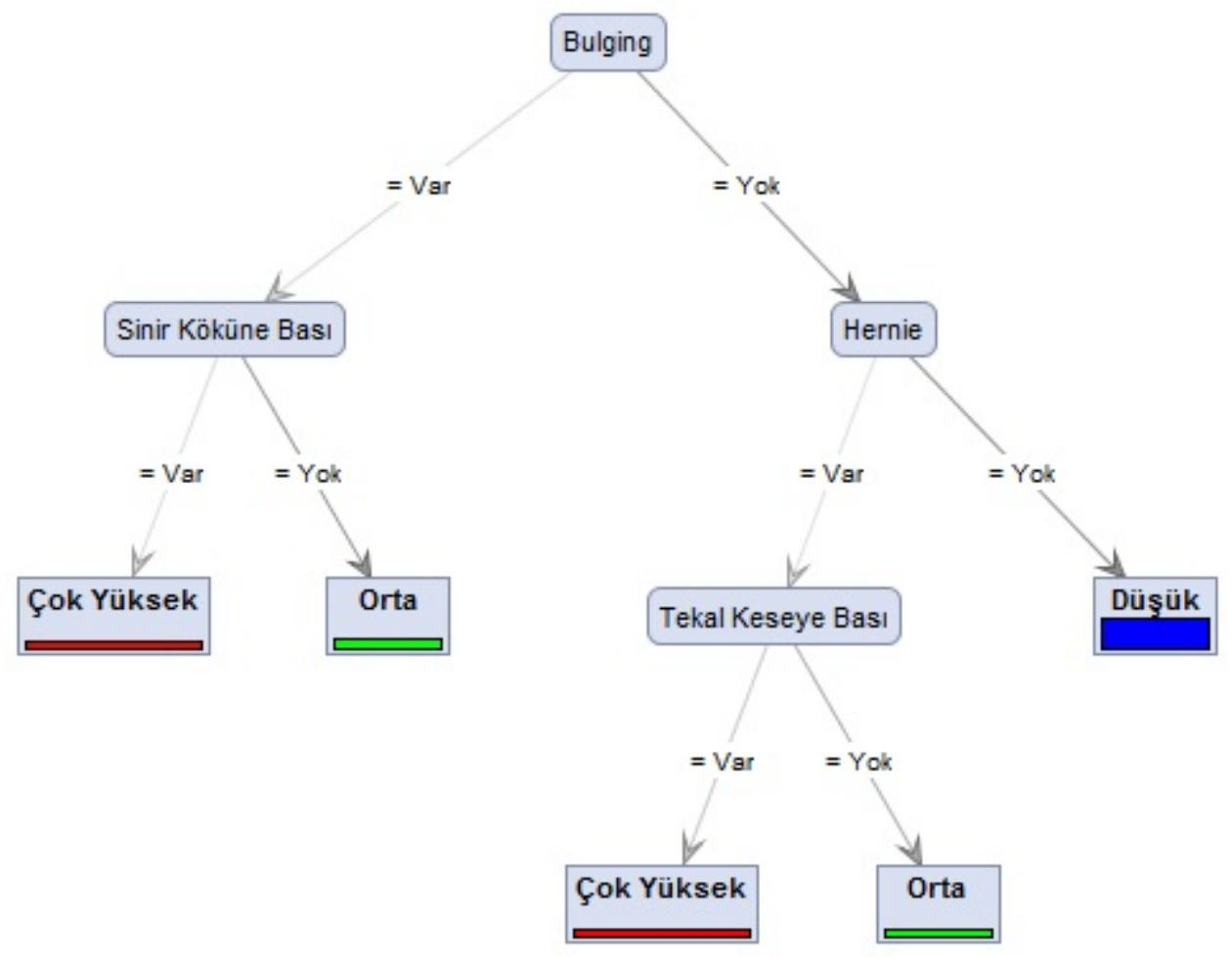

Şekil 8: L2-3 Veri Setine Göre ID3 Sınıflandırma Algoritmasının Ağaç Yapısı

Tree

Bulging $=$ Var

| Sinir Köküne Bası $=$ Var: Çok Yüksek $\{$ Düşük $=0$, Orta $=0$, Çok Yüksek $=1\}$

| Sinir Köküne Bası $=$ Yok: Orta $\{$ Düşük $=0$, Orta $=9$, Çok Yüksek $=0\}$

Bulging $=$ Yok

| Hernie $=$ Var

| | Tekal Keseye Bası = Var: Çok Yüksek $\{$ Düşük=0, Orta=0, Çok Yüksek=1 $\}$

| | Tekal Keseye Bası = Yok: Orta $\{$ Düşük $=0$, Orta=2, Çok Yüksek=0 $\}$

| Hernie $=$ Yok: Düşük $\{$ Düşük $=52$, Orta $=0$, Çok Yüksek=0 $\}$

Tablo 4: L2-3 Lomber Vertebra Omurundaki Veri Seti Doğruluk (Accuracy)

\begin{tabular}{|c|c|c|c|c|}
\hline \multicolumn{3}{|c|}{ (-) Multiclass Classification Performance $\bigcirc$ Annotations } & & 回 \\
\hline \multicolumn{5}{|c|}{ (-) Table View PlotView } \\
\hline \multicolumn{5}{|l|}{ accuracy: $94.74 \%$} \\
\hline & true Düșük & true Orta & true Çok Yüksek & class precision \\
\hline pred. Düșük & 13 & 0 & 0 & $100.00 \%$ \\
\hline pred. Orta & 0 & 5 & 1 & $83.33 \%$ \\
\hline pred. Çok Yüksek & 0 & 0 & 0 & $0.00 \%$ \\
\hline class recall & $100.00 \%$ & $100.00 \%$ & $0.00 \%$ & \\
\hline
\end{tabular}


- L3-4 Vertebra Lomber ID3 Algoritma Grafiği , Karar Ağacı Algoritması ve Doğruluk Tablosu:

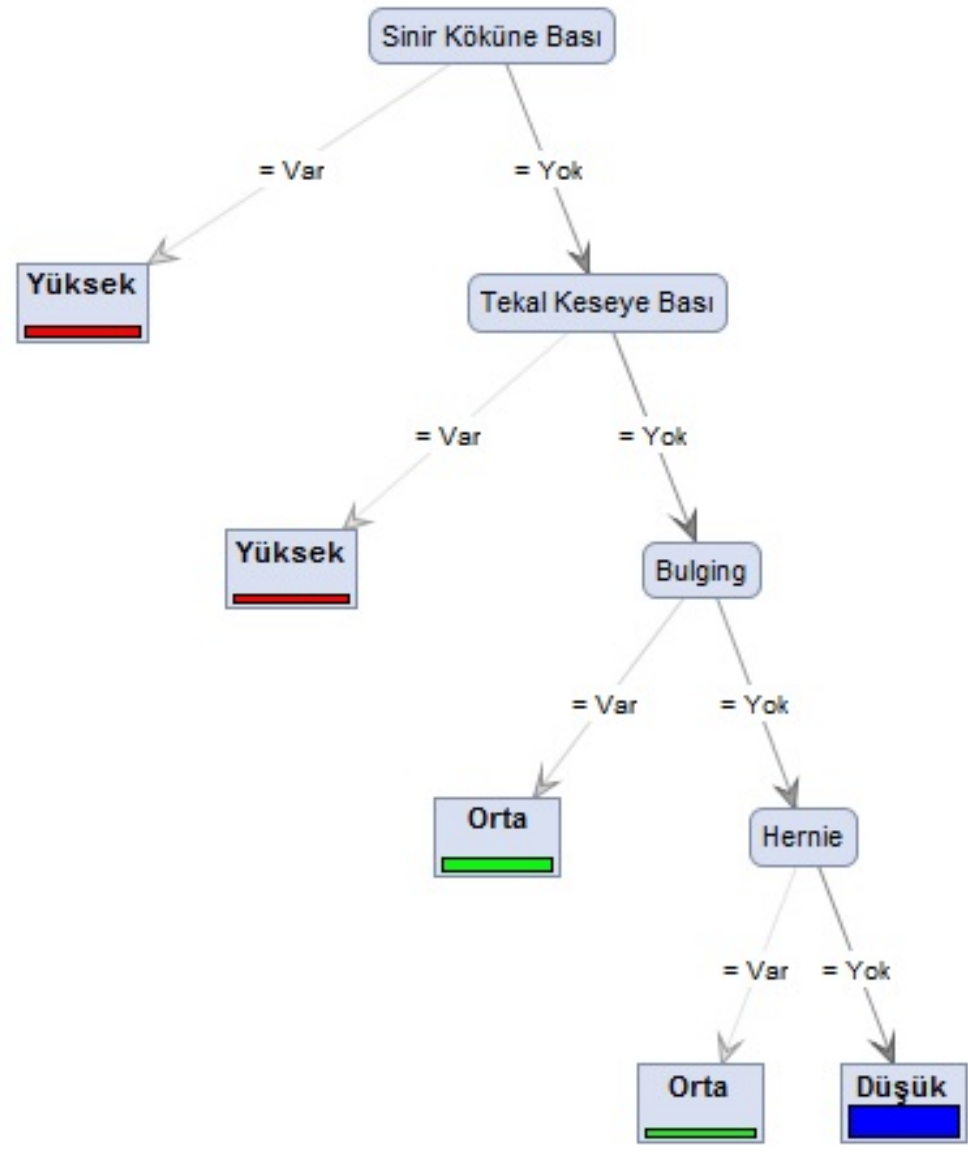

Şekil 9: L3-4 Veri Setine Göre ID3 Sınıflandırma Algoritmasının Ağaç Yapısı

Tree

Sinir Köküne Bası $=$ Var: Yüksek $\{$ Düşük $=0$, Orta $=0$, Yüksek $=5\}$

Sinir Köküne Bası = Yok

| Tekal Keseye Bası $=$ Var: Yüksek $\{$ Düşük=0, Orta $=0$, Yüksek=1 $\}$

| Tekal Keseye BasI = Yok

| | Bulging = Var: Orta $\{$ Düşük $=0$, Orta $=12$, Yüksek=0 $\}$

| | Bulging $=$ Yok

| | | Hernie = Var: Orta $\{$ Düşük=0, Orta=1, Yüksek=0 $\}$

| | | Hernie $=$ Yok: Düşük $\{$ Düşük $=46$, Orta=0, Yüksek=0 $\}$ 
Tablo 5: L3-4 Lomber Vertebra Omurundaki Veri Seti Doğruluk (Accuracy)

\begin{tabular}{|c|c|c|c|c|}
\hline (-) Multiclass & rmance $\bigcirc$ & & & 目 \\
\hline (C) Table Vie & & & & \\
\hline accuracy: 9 & & & & \\
\hline & true Düșük & true Orta & true Yüksek & class precision \\
\hline pred. Düșük & 11 & 0 & 0 & $100.00 \%$ \\
\hline pred. Orta & 0 & 5 & 1 & $83.33 \%$ \\
\hline pred. Yüksek & 0 & 0 & 2 & $100.00 \%$ \\
\hline class recall & $100.00 \%$ & $100.00 \%$ & $66.67 \%$ & \\
\hline
\end{tabular}

- L4-5 Vertebra Lomber ID3 Algoritma Grafiği , Karar Ağacı Algoritması ve Doğruluk Tablosu:

L4-5 Vertebra Lomber diski ile ilgili analizlerde, diğer disk seviyelerinden farklı olarak cinsiyet faktörü de program tarafından dahil edilmiştir.

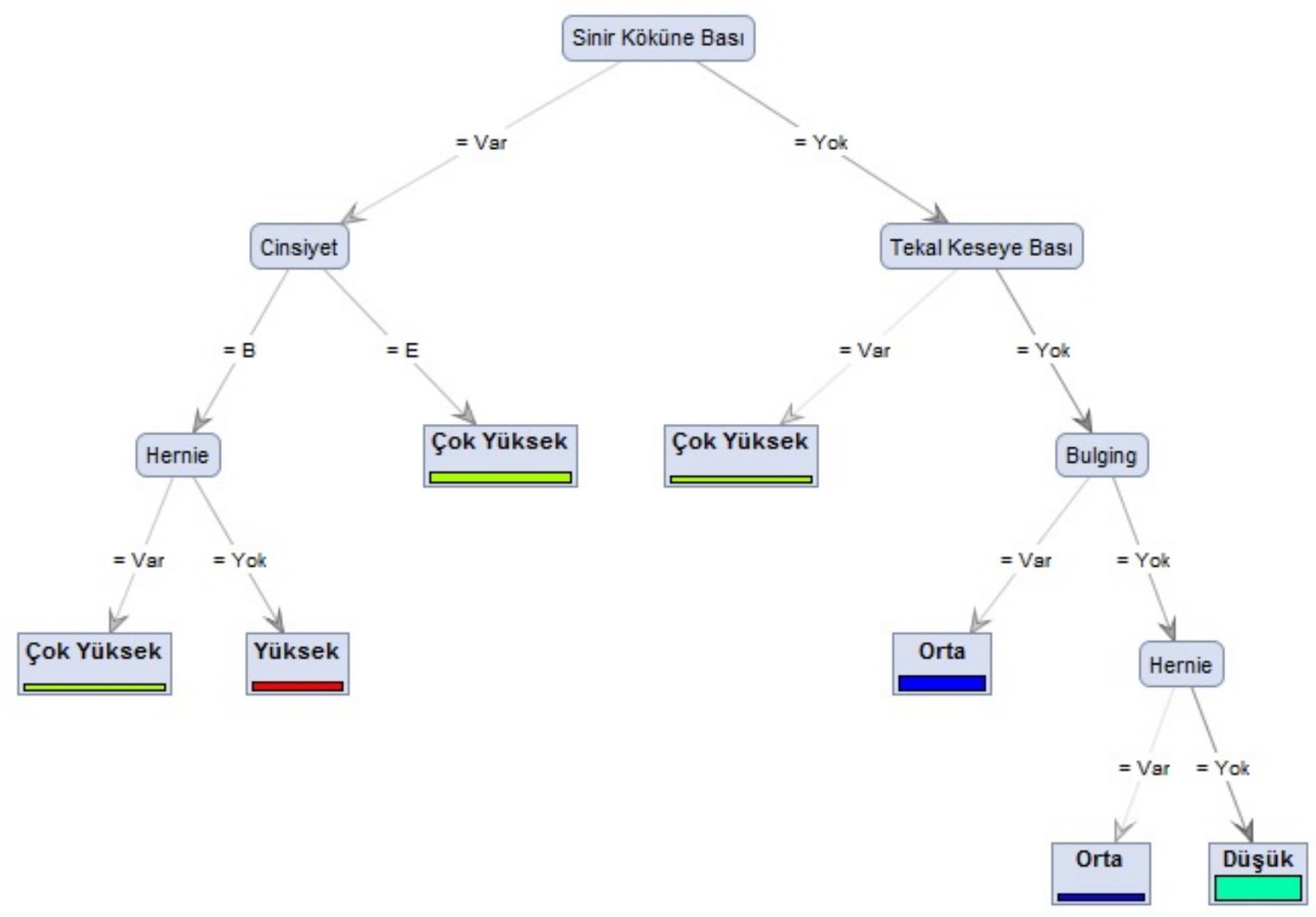

Şekil 10: L4-5 Veri Setine Göre ID3 Sınıflandırma Algoritmasının Ağaç Yapısı

Tree

Sinir Köküne Bası $=$ Var 


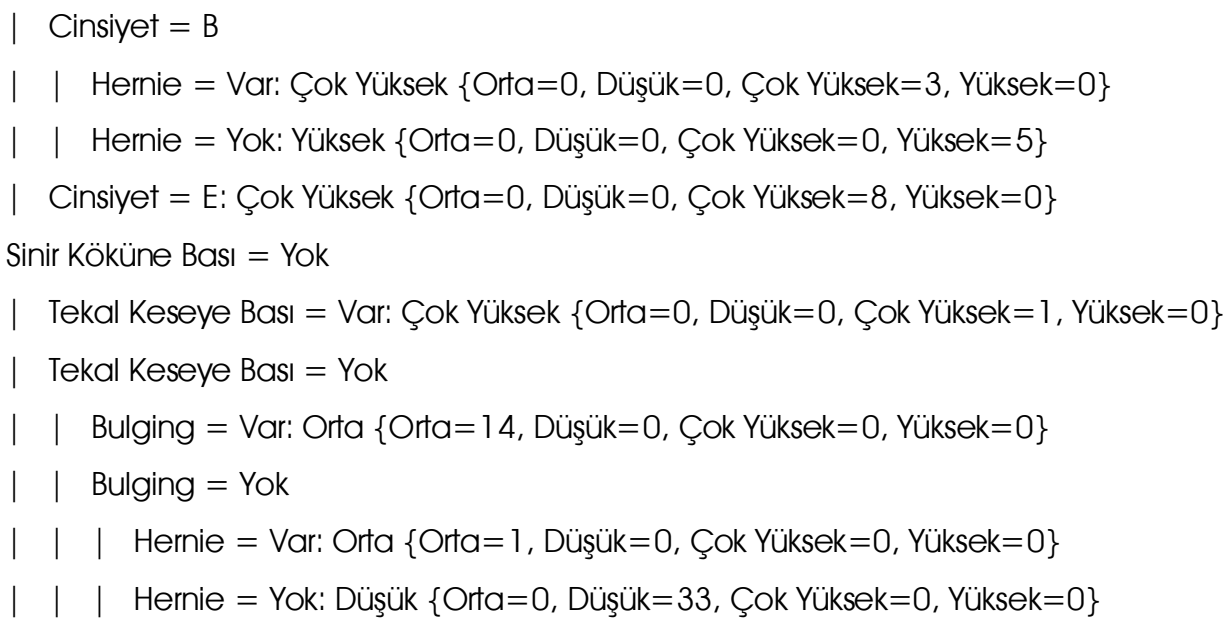

Tablo 6: L4-5 Lomber Vertebra Omurundaki Veri Seti Doğruluk (Accuracy)

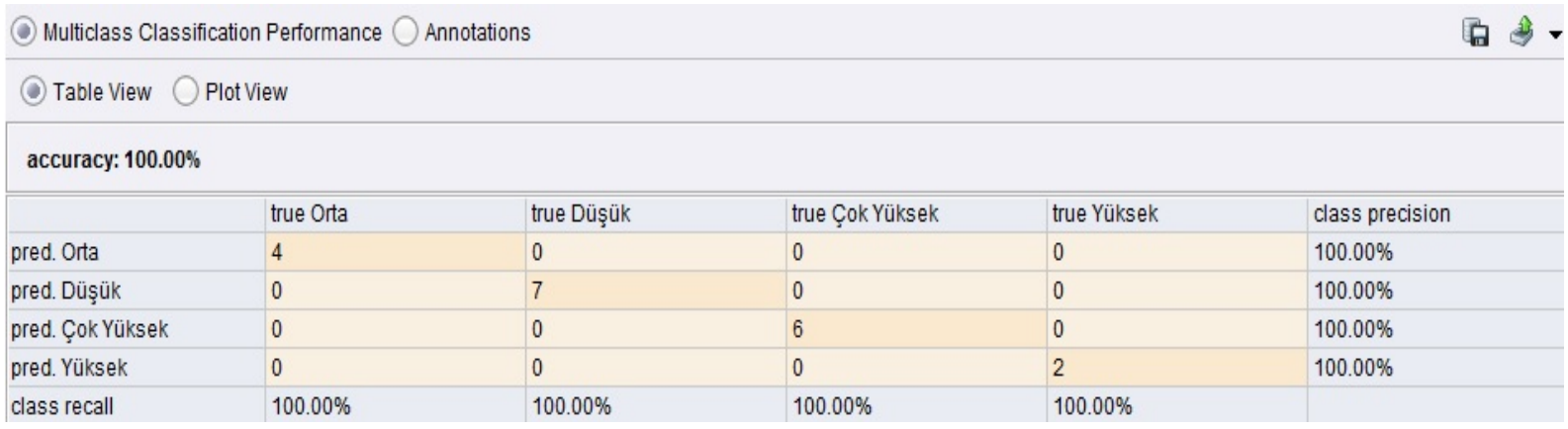

\section{SONUÇ}

Çalışma yaşamının ofis ortamlarına taşınması ile birlikte; omurga üzerine binen yükün ve uzun süreli oturmaya bağlı postür bozukluklarının artmasına neden olmuştur. İnsan vücudunun doğal formu ayakta duruşa uygundur. İnsan vücudunun dengesini sağlayan omurga, oturma / eğilme sırasında bükülme hareketi nedeniyle omurlar arasındaki disklerde zorlanmaktadır. Sürekli gerçekleşen bu zorlanmalar zamanla disk yapılarında bozulmalara neden olmakta; yaşa bağlı olarak disk (lerin) nucleus pulposus bölgelerinde sıvı kayıpları da gerçekleştiğinde, yaşam kalitesini tehdit eden rahatsızlıklar olarak karşımıza çıkmaktadır. Halk arasında bel ve boyun fıtığı olarak ifade edilen bu rahatsızlıklardan bel fıtığı, insan hayatını zorlaştıran kalp rahatsızlıklarından sonra ikinci sırada yer almaktadır. Bu denli yaygın bir rahatsızlığın çözüm yöntemleri de çok ve çeşitlidir.

Bel omurlarındaki rahatsızlığın tespitinde uzman doktor tarafından fizik muayenesi ve gerekiyor ise tıbbi görüntüleme ile tespit edilmekte; rahatsızlığın düzeyi hakkında karar verilmekte ve buna bağlı tedavi yöntemleri seçilmektedir. Uzman doktorların bel omurları 
ve bağlı disklerde meydana gelen rahatsızlıkların tespiti konusunda başvurdukları en yaygın yöntemlerden biri Manyetik Rezonans Görüntüleme ( MRG) tekniğidir. MRG, yumuşak doku rahatsızlıklarının tespitinde önemli rol oynamaktadır.

Tam teşekküllü bir kamu sağlık kuruluşuna çeşitli rahatsızlık şikayetleriyle başvuran hastalar arasından 1 Mart - 5 Nisan tarihleri arasında ilgili servislerden yönlendirilen ve bel MRG'si çekilen 65 hastanın verilerinden yola çıkılarak, bel rahatsızlığı risk durumlarının analiz edildiği çalışmada, benzeri şikayette gelen hastanın MRG bulgularından yola çıkılarak bel fıtığ1 riskinin seviyesi hakkında durum tespiti yapabilecek ve uzman doktora uygulanacak tedavi hakkında ön fikir oluşturacak bir karar ağacı yapısı oluşturulmaya çalışılmıştır.

Çalışma benzer alanda yapılmış çalışmalara ait literatürün azlığı bakımından önemlidir. Ayrıca, gelecekte bel ve omurganın diğer bölgelerinde meydana gelen rahatsızlıkların tespitinde ve uygulanacak tedavide etken rol oynayacak bir görüntüleme / tanı cihaz veya yöntemine yol gösterici olabileceği düşünülmektedir.

Çalışma sırasında hasta verilerinin her sağlık kuruluşunda ayrı ayrı tutulduğu ve dolayısıyla bir hastanın farklı sağlık kuruluşlarından veya hekimlerden görüş almak istediğinde, bu süreci tekrarlaması gerektiği görülmüş olup; sağlık sisteminin dağıtık bilişim sistemleri esasına dayanan ve yetkili kişilerce erişim sağlanabilen bir veri modeline ve ağ yapısına kavuşturulabileceği; bu alanda yapılabilecek bir çalışmanın hem kaynak, hem iş gücü bakımından tasarruf sağlayacağı düşünülmektedir.

\section{Kaynaklar}

Koç, K., “Bel Ağrısı ve Dejeneratif Lomber Disk Hastalığı” , ww.belgeler.com/blg/1ksq/disk-hern2003

Ünal, D., “Tıpta Kullanılan Görüntüleme Teknikleri”, Gazi Eğitim Fakültesi, Ankara, 2008

Oyar, O., "Manyetik Rezonans Görüntüleme (MRG)'nin Klinik Uygulamaları ve Endikasyonları”, Tip Dergisi, Harran Üniversitesi, 2008

Karahasanoğlu, V., "Magnetik Rezonans Görüntüleme Ve Görüntü Netleştirme”, Yüksek Lisans Tezi, Şubat, 2007

Karaoğuz,M.R., Oğuz,D., Kayhan Altuner, T., “Manyetik rezonans ortamı için geliştirilmiş kalp pilleri", Türk Kardiyol Derneği Arş., 2012

Orhan, U., "Makine Öğrenmesi Dersi", Çukurova Üniversitesi, Bilgisayar Mühendisliği Bölümü, 2012, http://bmb.cu.edu.tr/uorhan/Dersnotu/Ders03.pdf 
Özkan, Y., “Veri Madenciliği Yöntemleri”, Papatya Yayıncılık, 2008

Koyuncugil, A.S., Özgülbaş N.,'Veri Madenciliği: Tıp ve Sağlık Hizmetlerinde Kullanımı ve Uygulamaları", Bilişim Teknolojileri Dergisi, CILLT: 2, SAYI: 2, Mayıs 2009

Ak,B., "Sağlıkta Yeni Hedef Dijital Hastaneler", Özel Toros Üniversitesi, Akademik Bilişim Konferansları, 2013

Yazıcı Demir, Ş., Taştekin, N., Birtane, M., "Lomber Omurganın Biyomekaniği”, Türkiye Klinikleri Fiziksel Tıp ve Rehabilitasyon Özel Dergisi, Cilt 4, Sayı 1, 2011

Murat, S., "Lomber Traksiyonun Subakut Lomber Disk Hernili Hastalarda Klinik Ve Fonksiyonel Durum Üzerine Etkisi", Uzmanlık tezi, Trakya Üniversitesi Tıp Fakültesi, 2007

Sesli, E., "Bel Ağrısına Tanısal Yaklaşım", http://www.belgeler.com/blg/2hde/bel-arilarina-tanisalyaklaim,2011

Çelikyay, F., "Vertebral Metastaz, Dejenerasyon Ve Spondilodiskitlerin Ayırıcı Tanısında NonCpmg Ss-Fse Difüzyon Ağırlıklı Mr Görüntülenmenin Katkısının Değerlendirilmesi", Uzmanlık Tezi, Ankara, 2008

http://www.tumradder.com/FileUpload/ds58732/File/manyetik_rezonans_goruntuleme_mrg_.pdf

Türkiye Omurilik Felçlileri Derneği, http://www.tofd.org.tr/k2/Saglik_130.aspx

http://www.sciencedirect.com/science/article/pii/S1877132710001776

http://www.konez.com/MRG_goruntu_olusturulmasi.htm

nucleusanimation, http://www.youtube.com/watch?v=nV4ILsaVSXc\&NR=1\&feature=endscreen, 2011 